\title{
Expression of NR1 subunit of NMDA receptor and PSD-93/95 in rat hippocampus affected by NR1/NR2 antisense oligodeoxynucleotide
}

\author{
Monika Vrajová1*, Věra Bubeniková-Valešová', Jan Klaschka² \\ From $1^{\text {st }}$ International Congress on Neurobiology and Clinical Psychopharmacology \\ and European Psychiatric Association Conference on Treatment Guidance \\ Thessaloniki, Greece. 19-22 November 2009
}

\section{Background}

Abnormal protein expression of $\mathrm{N}$-methyl-D-aspartate (NMDA) receptors essential subunits (NR1, NR2) and of associated post-synaptic density proteins (PSD-95, PSD-93) were observed in schizophrenic patients (postmortem studies) [1,2]. NMDA receptors containing NNR2A/B subunit associate in vivo at synapses with PSD-93 and PSD-95 [3]. In the present study, we have silenced the expression of NR1 and/or NR2 proteins in vivo with the goal of assessing the influence of that protein's alteration on the prepulse inhibition of acoustic startle reaction (PPI) and on the expression of related PSD-95/PSD-93 proteins.

\section{Materials and methods}

We used antisense oligodeoxynucleotide for NMDANR1 individually or in combination with NR2A or NR2B (aNR1, aNR2A, aNR2B) in the rat hippocampus and evaluated the PPI. Western blot was employed to assess the expression of affected proteins (NR1, NR2A and NR2B) and associated PSD-95/93 proteins.

\section{Results}

Changes in expression of NR1 were found. We observed a significant decrease in the hippocampi of rats affected by the combination aNR2A/aNR2B when compared with controls; yet we did not detect changes in other applications. In addition, we found significant changes in the expression of PSD-95, namely a decreased level of this protein in groups treated with NR2A or NR2B. There were no significant changes in NR2A/B and PSD-93 expression and in PPI.

\section{Conclusions}

Despite the fact, that the short term silencing of NR1/ NR2 did not change PPI, there were changes in expression of PSD-95, which were connected with the NR2A/ $B$ subunit whose protein expression was not changed. This suggests that the association of PSD-95 with NR2A/B may occur in the early phase of biosynthesis.

\section{Acknowledgements \\ This work was supported by grants GAČR 309/09/HO72 and MŠMT ČR $1 \mathrm{M} 0517$.}

\section{Author details}

'Prague Psychiatric Center, Prague, Czech Republic. Institute of Computer Science, Academy of Sciences, Prague, Czech Republic.

Published: 22 April 2010

\section{References}

1. Kristiansen LV, Beneyto M, Haroutunian V, Meador-Woodruff JH: Changes in NMDA receptor subunits and interacting PSD proteins in dorsolateral prefrontal and anterior cingulated cortex indicate abnormal regional expression in schizophrenia. Mol Psychiatry 2006, 11:737-747.

2. Clinton SM, Haroutunian VH, Meador-Woodruff JH: Up-regulation of NMDA receptor subunit and post-synaptic density protein expression in the thalamus of elderly patients with schizophrenia. J Neurochem 2006, 98:1114-1125.

3. Sans N, Petralia RS, Wang YX, Blahos J, Hell JW, Wenthold RJ: A developmental change in NMDA receptor-associated proteins at hippocampal synapses. J Neurosci 2000, 20:1260-1271.

doi:10.1186/1744-859X-9-S1-S147

Cite this article as: Vrajová et al.: Expression of NR1 subunit of NMDA receptor and PSD-93/95 in rat hippocampus affected by NR1/NR2 antisense oligodeoxynucleotide. Annals of General Psychiatry 2010 9(Suppl 1):S147.

${ }^{1}$ Prague Psychiatric Center, Prague, Czech Republic 